\title{
Sharing the University-enterprise Cooperation Analog Electronic Technology Course Development
}

\author{
Haiyan Wang \\ Changchun University of Science and Technology, Changchun 130000, China \\ 13742883@qq.com
}

Keywords: school-business-shared curriculum, analog electronics, project-based teaching.

\begin{abstract}
The purpose and sign ificance to develop school- business p artn ership sharin ganalog electronics are described and the design concept provided. A ccording to the innovative concept, project-based teaching of the school- busines partnership with analog electron icsshared is selected. The principle of the developm ent for school-business shanng curriculum is described. The teaching shows that the develop ment of school- business sharing analog electronics is effective. And the new curriculum development methods prove to be ap propriate for vocational higher education.
\end{abstract}

\section{Shared between analog electronic technology course development of purpose and meaning}

"Analog electronic technology" is a professional basic course of electronic related majors in higher vocational colleges, is the basis of students' various needs in electronics industry jobs skills, also for the sustainable development of students in the electronic industry The foundation. But the theory and application "analog electronic technology" is stronger, the current teaching, theory and practice, practice and application, students' learning interest is not high. Therefore, an urgent need to change a new teaching method to substation engineering based teaching. The author combined with years of experience and a wide range of research, put forward a kind of Shared between colleges development method of the analog electronic technology course. Course construction, the enterprise to participate in all the way, following the work area and typical work tasks, learning areas, and then to the teaching purpose of a logical line of the curriculum system constructing. The course construction patterns on the premise of reducing production cost of running a school and sharing between production and teaching resources, build the base for training and internship practice, cultivate students or staff together, jointly formulate training programs is to enterprises, schools, students tripartite win-win a kind of teaching mode.

\section{Shared between analog electronic technology course design according to project plan and teaching}

Sharing type analog electronic technology course development between colleges try to solve the problem of enterprises are faced with the electricity class basis as the goal, to student career oriented curriculum development method. Cooperative enterprises to participate in school organization, make scientific evaluation on the industry and the needs of students, on the basis of the nature of the school itself, characteristics, conditions, make full use of enterprise and school curriculum resources on the basis of the established organization collaborative curriculum goals, choose curriculum content, curriculum implementation scheme decision, course evaluation such a continuous improvement process and dynamic course.

It is essentially the school and enterprise as the base, teachers and enterprise technical personnel to participate in as the main body, of course selection, adaptation, integration, or the process of new designed to meet the requirements of enterprise, to the students' career development as the starting point. School ACTS as the initial testing of new technology and new products, the enterprise senior engineering and technical personnel as students the guidance of teachers. Students type in Shared university-enterprise cooperation mode, the course can be obtained based on the work experience and 
knowledge, to the team as a unit, of students' autonomous management, independent learning, independent exploration, teachers, and corporate guidance teachers bear asked. Based on the concept of curriculum development, and cooperative enterprises with the analog electronic technology course construction has carried on the preliminary exploration. Cooperative enterprises according to the requirements of the enterprise research and development production, to determine the needs of the company for mold electricity class knowledge mainly focused on the jobs are shown in table 1.On this basis, the enterprise experts into the corresponding typical tasks, then through professional teachers and experts to determine the corresponding area of study and teaching project. After confirmed the sharing between analog electronic technology courses teaching Plan as shown in table 1.

Table 1. University-enterprise sharing type analog electronic technology course teaching program

\begin{tabular}{|c|c|c|c|}
\hline Typical jobs & Work task & Learning areas & Project teaching \\
\hline $\begin{array}{c}\text { The mechanic } \\
\text { operation }\end{array}$ & $\begin{array}{l}\text { Component identification } \\
\text { and detection } \\
\text { Electronic products of } \\
\text { welding } \\
\text { The assembly of electronic } \\
\text { products } \\
\text { Electronic circuit analysis }\end{array}$ & $\begin{array}{c}\text { Basic knowledge of } \\
\text { semiconductor components }\end{array}$ & $\begin{array}{l}\text { Linear power } \\
\text { supply welding and } \\
\text { production }\end{array}$ \\
\hline $\begin{array}{c}\text { The hardware } \\
\text { developer }\end{array}$ & $\begin{array}{c}\text { Electronic circuit drawing } \\
\text { Printed circuit board } \\
\text { design } \\
\text { The design and } \\
\text { manufacture of small } \\
\text { electronic products and } \\
\text { production }\end{array}$ & $\begin{array}{l}\text { Semiconductor components } \\
\text { basic knowledge, principle of } \\
\text { circuit analysis, circuit } \\
\text { simulation }\end{array}$ & $\begin{array}{l}\text { The design and } \\
\text { manufacture of the } \\
\text { charger }\end{array}$ \\
\hline $\begin{array}{c}\text { Qualitative } \\
\text { check member }\end{array}$ & $\begin{array}{c}\text { Electronic product } \\
\text { assembly and wiring } \\
\text { Electronic product quality } \\
\text { testing } \\
\text { Product failure analysis } \\
\text { Data statistics and analysis } \\
\text { Product quality status } \\
\text { identification } \\
\text { Electronic circuit analysis }\end{array}$ & $\begin{array}{l}\text { Basic knowledge of } \\
\text { semiconductor components } \\
\text { Function, circuit analysis, } \\
\text { Amplifying circuit and the } \\
\text { application of integrated } \\
\text { operational amplifier circuit, } \\
\text { Signal generating circuit }\end{array}$ & $\begin{array}{l}\text { Voice control } \\
\text { circuit design and } \\
\text { verification }\end{array}$ \\
\hline $\begin{array}{c}\text { Product } \\
\text { stewardship }\end{array}$ & $\begin{array}{l}\text { Electronic product } \\
\text { technical indicators of test } \\
\text { Electronic product } \\
\text { technical indicators of test } \\
\text { Electronic product failure } \\
\text { analysis and maintenance }\end{array}$ & $\begin{array}{l}\text { Semiconductor components are } \\
\text { the basic knowledge, } \\
\text { Circuit analysis function, } \\
\text { Amplifying circuit and the } \\
\text { application of integrated } \\
\text { operational amplifier circuit, } \\
\text { Function signal generating way }\end{array}$ & $\begin{array}{c}\text { Function signal } \\
\text { have the design and } \\
\text { validation }\end{array}$ \\
\hline
\end{tabular}

\section{Shared university-enterprise cooperation principle of curriculum development}

The table 1 shows that according to the needs of the enterprises and students lack of the knowledge structure, we study together with enterprises, and determine the students must learn in the analog electronic technology course, and thus the teaching project is determined.

These courses teaching Eye can meet the requirements of the students can also meet the needs of the enterprise as part of the new employee.

Make sure the teaching project, should be based on the actual enterprise needs, and according to the enterprise research and development process to arrange and implement principle is as follows: 
Organic combination: theoretical study and project teaching organic combination, have bigger coincidence degree, and the project should be enterprise project products are applied;

On job - fixed: students in cooperation course semester, with the identity of "staff" joined the class project in the learning process, such as conditions permit, the cooperative enterprise shall be provided to the students' real jobs.

Process supervision: the students to participate in corporate cooperation courses during learning, the students will become ACTS brother and the enterprise member T, designed the school teachers and enterprises as the master, to the student's $\mathrm{T}$, process supervision enterprises according to according to the rules and regulations for students in the whole management, hencoop students in $T$ for the performance evaluation, to ensure the quality of the work term.

Evaluation: the students complete the work term, results and experience of work term, summarizes in writing, teachers and experts in accordance with the enterprise performance evaluation standard about performance appraisal to the students, and record the results of the appraisal, as the main basis of examination.

\section{The teaching effect}

University-enterprise cooperation sharing type analog electronic technology course, obtain obvious teaching effect. One is the study effect is good. More than $90 \%$ after learning this course, students can complete simple circuits; $20 \%$ of the students can complete all extracurricular independent development tasks. Second, the study interest to improve. Since the curriculum reform, the students' attendance reached more than $98 \%$, job done faster, soon beginning ability enhanced obviously, student satisfaction rate above $90 \%$.

After preliminary exploration, shared university-enterprise cooperation analog electronic technology course development experience. [for a field, typical $\mathrm{T}$ for a task, learning areas, to the teaching project and so on several stages, the development process, enterprises to participate in all the way, has realized the curriculum development of the following features: (1) the case teaching of the course are all made of cooperative enterprises are implementing or have implemented classic project, at the scene of the internship teaching cases, so that the students in order to solve the practical problems and clear their own learning goals. (2) corporate involvement in curriculum design: the whole process of the implementation of the curriculum development and test engineers or technicians must have enterprise full participation.At all stages of program implementation, students in the school of enterprise under the guidance of the steering group, through self-study, tutoring, enterprise field teaching, seminar, post-practice, and other forms to complete the course Learning tasks. (3) Comprehensive reform test way: on the basis of the actual project enterprise, in order to solve practical problems of enterprises as the fundamental, with an emphasis on skills examination.

Through the course of development, the enterprise both for his first reserve and select match with the corporate culture created prerequisites of useful talents, and also can through the cooperation education of students to promote their corporate culture to the society; Project course teaching resources, school and enterprise sharing, both can be used for school teaching, also can be used as a new member for the enterprise I training programs; Through the curriculum development cooperation, the school of extra high quality human resources can provide enterprises with new technical support, a line member companies can be thought that the school teaching practice project support.

Therefore, sharing type university-enterprise cooperation development and practice of analog electronic technology course for higher vocational colleges' professional basic course and specialized course, etc. Provide some useful reference for the construction of the course.

\section{References}

[1] Guo Pan feng, sun, SuShiWei. Chinese-foreign cooperation in running schools under the analog electronic technology course teaching mode reform research [J]. Journal of the new curriculum research (the ten-day), 2016, (10): 19 to 20. 
[2] Yun-juan sun. Analyze the local factors: under the background of transition and development in colleges and universities curriculum development, electronic information engineering, for example [J]. Journal of Guangxi College of education, 2016, (5): 150-152.

[3] Hu Renhui. Electronic information engineering specialty talents training mode of study [J]. Journal of wireless technology, 2016, (18): 79-80.

[4] Guang-xing li, zhu lili. Action-oriented teaching mode in higher vocational college of electronic information engineering technology professional talent training implementation [J]. Journal of education and profession, 2015, (02): 160-161.

[5] Ceng Heqiong Hu Jun. Independent college teaching analog electronic technology course project development and design [J]. Science Tribune (ten-day), 2014, (10): 202-203.

[6] Li wei, wan-li Chen. Applied electronic information professional talent training mode reform research and practice [J]. China power education, 2014, (12): 16-17.

[7] QinWenShi Chen Dachang. Application of electronic technology professional "university -enterprise cooperation and work-integrated learning" cultivation mode exploration [J]. Journal of enterprise reform and management, 2014, (8): 86-87.

[8] Wei-feng zhang. Shared university-enterprise cooperation analog electronic technology course development [J]. Journal of Shenzhen institute of information technology, 2012, (4): 99-101. 